УДК $378 ; 371.134 ; 373.5 .016(043.3)$

DOI:

Агнета Маргітич, аспірант спеціальності 011 “Освітні, педагогічні науки” Мукачівського державного університету

\title{
АНАЛІЗ НОРМАТИВНО-ПРАВОВОГО ЗАБЕЗПЕЧЕННЯ ОРГАНІЗАЦИЙНОЇ КУЛЬТУРИ КОЛЕДЖУ В УМОВАХ ПОЛІКУЛЬТУРНОСТІ
}

У статті здійснено аналіз нормативно-правових актів щзоо регулювання організаційної культури коледжу в умовах полікультурного середовища. Визначено основні положення законів "Про освіту”, "Про вищу освіту Закон "Про громадянство”, “Про національні меншини в Украӥні", “Стратегія національнопатріотичного виховання дітей та молоді на 2016-2020 роки” (2015), "Національна стратегія у сфері прав людини” (2015). Підкреслено, щьо організаційна культура - це філософські та ідеологічні уявлення, цінності, переконання, вірування, очікування, норми, які поєднують організацію в єдине иіле і приймаються ї̈ членами. Схарактеризовано, що визначення конкретних кроків на шляху формування громадянських иінностей в Україні, план заходів щодо зміџнення національної єдності, консолідації украйнського суспільства та підтримки ініціатив громадськості були представлені у положеннях документа "Про пріоритетні заходи щодо сприяння зміџненню наиіональної єдності та консолідації українського суспільства, підтримки ініціатив громадськості у иій сферi" (2018).

Ключові слова: закон; організачійна культура; коледж; полікультурне середовище.

Лim. 13.

Agneta Margitich, Postgraduate Student majoring in specialty 011 "Educational, pedagogical sciences" Mukachevo State University

\section{ANALYSIS OF REGULATORY AND LEGALSUPPORT OF THE ORGANIZATIONAL CULTURE OFTHE COLLEGE IN THE CONDITIONS OF POLYCULTURALITY}

The article analyzes the legal acts governing the organizational culture of the college in a multicultural environment. The main provisions of the laws "On Education", "On Higher Education" Law "On Citizenship", "On National Minorities in Ukraine", "Strategy of national-patriotic education of children and youth for 2016-2020" (2015), "National Strategy for Human Rights" (2015). It is emphasized that organizational culture is a philosophical and ideological ideas, values, beliefs, and expectations, norms that unite the organization into a single whole and are accepted by its members. An identification of specific steps towards the formation of civic education in Ukraine, a plan of measures to strengthen national unity, consolidation of Ukrainian society and support of public initiatives were presented in the document "On priority measures to promote the strengthening of national unity and consolidation of Ukrainian society, support for public initiatives in this area" (2018). It is emphasized that an important element of civic education should be the formation of a responsible attitude of citizens to the protection of the sovereignty and territorial integrity of Ukraine, ensuring security and awareness of the common interests of man and a state, the formation of skills necessary for active participation in democratic life, free society, in order to promote and protect democracy and the rule of law, as well as the development of national identity, which provides for the consolidation of the functioning of the state language in all spheres of public life, including respect and development of languages of all national minorities and indigenous peoples living in Ukraine. It is revealed that among the main tasks of the multicultural environment is the formation of intercultural mentality, receptivity to cultural pluralism, universal values, tolerant attitude to other cultures and traditions; developing a negative attitude towards any form of violence; active prevention of tendencies to reveal destructive nationalism, which directly influence the organizational culture of the college, which operates in a multicultural environment.

Keywords: law; organizational culture; college; multicultural environment.

П остановка проблеми. Труднощі відродження національної ідентичності та розбудови громадянського суспільства, в Україні віддзеркалюються й удіяльності освітніх закладів. Механізм реалізації створення полікультурного середовища в закладах освіти має свої особливості, що полягають у визнанні пріоритету загальнолюдських цінностей у їх взаємозв'язку з національними. Одним із ключових завдань суспільства $є$ створення оптимальних умов для молодого покоління, адже саме молодь має бути спрямована на формування освіченої, творчої особистості, яка у майбутньому визначатиме перспективи та шлях розвитку нашої держави.

У контексті проблеми нормативно-правового регулювання організаційної культури закладів освіти важливого значення набуває грунтовне висвітлення стану формування комплексної ознаки в умовах полікультурного освітнього 
середовища. Нинішній суспільний запит щодо нормативно-правового регулювання зазначеної сфери потребує таких змін українського законодавства, щоб воно було здатним повною мірою забезпечити культурні інтереси здобувачів освіти та враховувало регіональні аспекти культурного розвитку. Період навчання студентів у коледжі є важливим для їх соціалізації як особистості, адже освіта - основа професійної майстерності, що виражається в усвідомленні життєвих перспектив, культури взаємин, адаптації в колективі та засвоєнні моральних цінностей, має вплив на формування організаційної культури власне ЗВО, що є одним із чинників загальної стратегії його організаційного розвитку.

Аналіз останніх досліджень та публікацій. Питання нормативно-правового регулювання освітньої сфери, різні аспекти організаційної культури освітнього закладу відображені в працях вітчизняних та зарубіжних дослідників Р. Кілмана, В. Лугового, В. Новикова, В. Петрушенко, Б. Савчука, О. Ярошинської та ін.

Аналіз досліджень засвідчує, що організаційна культура закладу вищої освіти стає важливим чинником підвищення ефективності навчання, розвитку творчих здібностей, формування особистості майбутнього спеціаліста, його професійної компетентності, громадської активності та формування його ціннісних орієнтацій. Р. Кілман [13], І. Ільїнська [6], О. Ярошинська [12] та інші підкреслюють, що умови діяльності сучасного ЗВО формують співробітництво учасників освітньої діяльності, тобто впливають на розподіл функцій, дій, єдність мети та сприяють активності у міжособистісних відносинах учасників освітньо-виховного процесу i педагогічній взаємодії в освітньому середовищі.

Мета статті: здійснити аналіз нормативноправових засад розвитку організаційної культури коледжу в умовах полікультурного середовища.

Виклад основного матеріалу. Полікультурне освітнє середовище - це сукупність підсистем, які цілеспрямовано забезпечують досягнення освітніх цілей учасниками освітнього процесу різних національностей і культур. Будучи носіями різних культур, учасники освітнього процесу будують взаємовідносини, виходячи зі своїх уявлень про взаємодію. Ці уявлення можуть не збігатися через культурні відмінності, різні систем цінностей, інше розуміння соціальних ролей тощо, але важливо, щоб взаємодія здійснювалася на основі принципів толерантності, взаємоповаги 3 урахуванням того, що культурні розбіжності потрібно не нейтралізувати чи контролювати, а організовувати педагогічну діяльність на основі забезпечення культурно-соціальної ідентифікації особистості, відкритості іншим культурам, національностям, расам, віруванням $[8,122]$.

Сучасні світові процеси глобалізації, інтеграції і диференціації культур зумовлюють необхідність такого поняття, як полікультурна освіта i встановлюють низку різноманітних умов для створення полікультурного середовища, в якій буде виховуватися сучасне покоління, готове до співпраці і взаємодії в багатонаціональному полікультурному суспільстві. Цей факт, на наш погляд, накладає особливу відповідальність на ЗВО загалом та на траєкторію формування цінностей щодо полікультурного виховання особистості майбутнього фахівця зокрема [6, 307].

Сучасний світ відчуває потребу в нових підходах, що будуть спрямовані на інтеграцію культур і народів для їх подальшого зближення і духовного збагачення. Звідси і значимість формування організаційної культури навчального закладу освіти в умовах полікультурного середовища, мета якої полягає у формуванні культури людини, залучення особистості до загальнолюдських цінностей, усвідомлення нею власної унікальності і створенні можливостей для творчої самореалізації особистості.

Зазначимо, що організаційна культура закладу вищої освіти, зокрема коледжу, регламентується нормативно-правовими актами та положеннями. Так, в статті 41 закону України "Про освіту" зазначається, що якісна освіта - це забезпечення наявності необхідних ресурсів для культури організації освітнього процесу, зокрема і для самостійної роботи здобувачів освіти; забезпечення наявності інформаційних систем для ефективного управління закладом освіти; створення в закладі освіти інклюзивного освітнього середовища, універсального дизайну та розумного пристосування [4].

Ми зосереджуємо увагу на організаційній культурі коледжу. Згідно із Законом України “Про вищу освіту” (2014), коледж - це заклад вищої освіти або структурний підрозділ університету, академії чи інституту, що провадить освітню діяльність, пов'язану із здобуттям ступеня бакалавра та/або молодшого бакалавра, проводить прикладні наукові дослідження та/або творчу мистецьку діяльність [1]. Водночас підкреслюється, що заклад вищої освіти діє на підставі власного статуту, яким визначається його організаційна структура та закріплюються права і обов'язки засновника; обсяг основних засобів, наданих засновником; повноваження органів управління закладу вищої освіти; права і обов'язки керівника закладу вищої освіти; порядок обрання 


\section{АНАЛІЗ НОРМАТИВНО-ПРАВОВОГОЗАБЕЗПЕЧЕННЯ ОРГАНІЗАЦЙНОӦ КУЛЬТУРИ КОЛЕДЖУ}

В УМОВАХ ПОЛІКУЛЬТУРНОСТІ

представників до органів громадського самоврядування тощо [5].

Оскільки організаційна культура - це “філософські та ідеологічні уявлення, цінності, переконання, вірування, очікування, аттітюди і норми, які пов'язують організацію в єдине ціле і розділяються іiі членами" [13], то важливим регламентуючим документом діяльності коледжу $€$ також Колективний договір, в якому можуть бути передбачені певні етичні правила, зокрема щодо академічної доброчесності, обмежень у прояві агресивної поведінки, визначені місія і соціальна мета коледжу.

Більшість дослідників підкреслюють регулюючий характер організаційної культури, передусім норм поведінки, тому що саме вона забезпечує цілісність на основі ключових цінностей та норм, що сприймаються членами колективу як засадничі та такі, що передаються у покоління до покоління, створює умови для залучення особистості до колективної діяльності, проектує перспективи розвитку організації, що базуються на цінностях, традиціях, нормах [6; 7]. Якщо беремо до уваги, що організаційна культура - це система відносин, цінностей, правил, норм, традицій, знаків, установок, що визначають стратегію розвитку поведінки у різних умовах та обставинах, то значний вплив на формування організаційної культури коледжу має полікультурне середовище.

У своїй діяльності фаховий коледж як організаційна структура, що провадить освітню діяльність в умовах полікультурного середовища, керується законодавчими актами і законами у сфері міжетнічних взаємин.

Під освітнім середовищем закладу освіти розуміється вся сукупність норм і правил, що регламентують і обмежують взаємини керівництва, педагогів та студентів, а також усіх груп зацікавлених осіб (вищих інстанцій, батьків, роботодавців, соціальних партнерів та ін.) [11]. Створення полікультурного освітнього середовища з урахуванням усіх визначених його компонентів $€$ потужним чинником у формуванні особистості сучасного фахівця, особистості зі сформованими гуманістичними цінностями

Більшість науковців поділяють думку, що середовище обумовлює поведінку людини, і ці умови можуть бути різнопланові: однонаправлена причинново-наслідкова обумовленість, коли середовище впливає на людину; однонаправлена причинново-наслідкова обумовленість, коли людина формує середовище; коли обидва способи існують одночасно; коли відбувається взаємодія між середовищем і людиною як інтерференція нестійкої рівноваги; коли взаємодія між середовищем і людиною відбувається як боротьба; коли людина і середовище складають єдину систему; випадкова обумовленість, у випадку якої загальний результат взаємодії не може бути передбачений $[6 ; 11]$.

Основні принципи нормативно-правової бази регулювання полікультурних і етнонаціональних процесів в Україні сформульовано в низці документів [2; $3 ; 9 ; 10]$. Зокрема, в Статті 1 Закону “Про національні меншини” наголошується, що Україна гарантує громадянам, незалежно від їхнього національного походження, рівні політичні, соціальні, економічні й культурні права і свободи, підтримує розвиток національної самосвідомості й самовиявлення. Стаття 6 цього Закону гарантує всім національним меншинам право на національну культурну автономію: користування й навчання рідною мовою чи вивчення рідної мови в державних закладах освіти або через національні культурні товариства, розвиток національних традицій тощо [3].

Питання розвитку полікультурного середовища були відображені і в “Національній стратегії сприяння розвитку громадянського суспільства в Україні на 2016-2020 р.” (2016), “Стратегії національно-патріотичного виховання дітей та молоді на 2016-2020 р.”(2015), "Національній стратегії у сфері прав людини" (2015), “Національній стратегії сприяння розвитку громадянського суспільства в Україні на 20212026 роки" (проєкт) та інших.

Визначення конкретних кроків на шляху формування громадянської освіти та її вплив на розвиток організаційної культури освітньої установи в Україні, план заходів щодо зміцнення національної єдності, консолідації українського суспільства та підтримки ініціатив громадськості були представлені у положеннях документа "Про пріоритетні заходи щодо сприяння зміцненню національної єдності та консолідації українського суспільства, підтримки ініціатив громадськості у цій сфері” (2016) [9].

Підкреслено, що вагомим елементом громадянської освіти має стати формування у громадян таких цінностей, як відповідальне ставлення до захисту суверенітету та територіальної цілісності України, забезпечення безпеки та усвідомлення спільності інтересів людини та держави, формування навичок, необхідних для активної участі у демократичному житті, вільному суспільстві, з метою заохочення та захисту демократії та верховенства права, а також розвиток національної ідентичності, що передбачає закріплення функціонування 


\section{АНАЛІЗ НОРМАТИВНО-ПРАВОВОГОЗАБЕЗПЕЧЕННЯ ОРГАНІЗАЦЙНОӦ̈ КУЛЬТУРИ КОЛЕДЖУ В УМОВАХ ПОЛІКУЛЬТУРНОСТІ}

державної мови в усіх сферах суспільного життя, включаючи повагу і розвиток мов усіх національних меншин та корінних народів, які проживають на території України.

Положення "Концепції розвитку громадянської освіти в Україні (2018) базуються на необхідності створення сприятливих умов для формування та розвитку громадянських компетентностей людини на всіх рівнях освіти та у всіх складниках освіти, що дасть змогу громадянам краще розуміти i реалізувати цінності демократії, відповідального ставлення до своїх прав й обов'язків, активної участі у суспільно-політичних процесах.

Як цінності захисту державності, здатності відстоювати свої права, відповідально ставитися до громадянських обов'язків, брати відповідальність за власне життя, за налагодження гармонійних стосунків між членами своєї сім'ї, за життя територіальної громади визначені метою громадянської освіти. Все ж вирішальним чинником становлення оргвізаційної культури є філософія і принципи, до яких спрямована освітня організація.

Завданнями сучасної освіти в умовах полікультурності визначаються: національної та культурної ідентичності; сприяння розвитку української мови, підвищення духовного рівня українського народу та усвідомлення його моральних норм; “формування поваги до честі та гідності людини, до прав та свобод людини, здатність їх захищати, громадянської відповідальності за суспільно-політичні процеси, набуття навичок здійснювати демократичне управління на місцевому рівні та навичок участі громадян у веденні державних справ; розвиток критичного мислення та медіаграмотності, вміння їх практичного застосування" [10]; формування навичок конструктивної міжособистісної та суспільної взаємодії, яка грунтується на взаємоповазі, обміну досвідом і співпраці; впровадження принципів солідарності та турботи про спільне благополуччя.

Висновки та перспективи подальших досліджень. Значимість організаційної культури для коледжу як конкурентоспроможної організації полягає в тому, що організаційна культура уможливлює вільний відбір найбільш ефективних для досягнення мети внутрішньоорганізаційних міжособистісних відносин, відповідних моделей поведінки персоналу. Сучасний коледж в полікультурних умовах - це освітня установа, яка діє на підставі нормативно-правових документів, які забезпечують регулювання і гармонізацію ділових й етичних відносин інтеркультурного характеру. Культивуючи такі цінності, як полікультурна толерантність, компетентність, творча спрямованість, готовність до зовнішньої і внутрішньої освітньої конкуренції (змагання), до роботи в команді, колективізм, гордість за свою установу, організаційна культура підвищує згуртованість співробітників, узгодженість їх поведінки, найбільш відповідної цілям організації. Добре сформована організаційна культура забезпечує співробітникам освітньої установи самостійно вибудовувати стратегію професійного самовизначення, кар'єрного зростання на нормативно-правовій основі.

Перспективи подальших досліджень вбачаємо у дослідженні впливу культурного плюралізму, толерантного ставлення до традицій інших народів на розвиток організаційної культури коледжу.

\section{ЛІТЕРАТУРА}

1. Закон України "Про вищу освіту” (2014). URL: https://zakon.rada.gov.ua

2. Закон України "Про громадянство” (1991). URL: https://zakon.rada.gov.ua.

3. Закон України "Про національні меншини в Україні” (1992, із змінами 2012, 2014). URL: https:/ zakon.rada.gov.ua/laws/show/2494-12\#Text

4. Закон України "Про освіту" (2017). URL: https://zakon.rada.gov.ua

5. ЗаконУкраїни "Про фахову передвищу освіту” (2019). URL: https://zakon.rada. gov.ua/ laws/show/2745-19\#Text

6. Ильинская И.П. Феноменология поликультурной образовательной среды: от концептуальных основ - к реалиям нравственно-эстетического развития личности. Российское учительство в модернизации духовно-нравственной культуры общества: традиции, судьбы, идеи. Опыт / под ред. А.В. Репринцева. Курск, 2011. С.300-310.

7. Новиков В.Н. Образовательная среда вуза как профессионально и личностно стимулирующий фактор. Электронный журнал "Психологическая наука и образование”. 2012. №1. URL: www.psyedu.ru

8. Петрушенко В.М. Голець Т. А. Когнітивна концепція крос-культурного менеджменту. Вісник СумДУ. Серія “Економіка”. 2008. № 1. С. 120 128.

9. Про пріоритетні заходи щодо сприяння зміцненню національної єдності та консолідації українського суспільства, підтримки ініціатив громадськості у цій сфері (2016). Указ Президента України від 01.12.2016 p. URL: https:// zakon.rada.gov.ua/laws/show/534/2016\#Text

10. Про схвалення Концепції розвитку громадянської освіти в Україні. Розпорядження 
Кабінету міністрів України від 3 жовтня 2018 р. № 710-p URL: https://zakon.rada.gov.ua/laws/show/ 710-2018-\%D1\%80\#Text

11. Савчук Б., Міщук Д. Освітнє середовище університету: методологічний дискурс у контексті складання міжнародних рейтингів. Молодь $i$ ринок. № 2.181 (2020). С. $60-64$.

12. Ярошинська О. О. Освітній простір вищого навчального закладу як континуум проектування освітнього середовища професійної підготовки майбутніх фахівців. Педагогіка формування творчої особистості у вищій $і$ загальноосвітній школах, 2014. Вип. 35. С. 558-567.

13. Kilmann R., Saxlon M. J. \& Serpa R. Issues in Understandingand Changing Culture. California Managment Review, Winter, 1986. P. 89.

\section{REFERENCES}

1. Zakon Ukrainy "Pro vyshchu osvitu" (2014). [Law of Ukraine "On Higher Education"]. Available at: https://zakon.rada.gov.ua [in Ukrainian].

2. Zakon Ukrainy "Pro hromadianstvo" (1991). [Law of Ukraine "On Citizenship"]. Available at: https://zakon.rada.gov.ua. [in Ukrainian].

3. Zakon Ukrainy "Pro natsionalni menshyny v Ukraini” (1992, iz zminamy 2012, 2014 r). [Law of Ukraine "On National Minorities in Ukraine"]. Available at: https://zakon.rada.gov.ua/laws /show/ 2494-12\#Text[in Ukrainian].

4. Zakon Ukrainy "Pro osvitu" (2017). [Law of Ukraine "On Education"]. Available at: https:// zakon.rada.gov.ua[in Ukrainian].

5. Zakon Ukrainy "Pro fakhovu peredvyshchu osvitu" (2019). [Law of Ukraine "On Professional Higher Education"]. URL: https://zakon.rada.gov.ua/ laws/show/2745-19\#Text[in Ukrainian].

6. Ilinskaya, I. P. (2011). Fenomenologiya polikulturnoy obrazovatelnoy sredy: ot kontseptualnykh osnov - k realiyam nravstvenno-esteticheskogo razvitiya lichnosti [Phenomenology of a multicultural educational environment: from conceptual foundations to the realities of moral and aesthetic development of the individual]. Russian teachers in the modernization of the spiritual and moral culture of society: traditions, destinies, ideas. Experience / ed. A.V. Reprintseva. Kursk, pp. 300-310.[in Russian].

7. Novikov, V.N. (2012). Obrazovatelnaya sreda vuza kak professionalno i lichnostno stimuliruyushchiy faktor [The educational environment of the university as a professionally and personally stimulating factor]. Electronic journal "Psychological Science and Education”. No. 1. Available at: URL: www.psyedu.ru [in Russian].

8. Petrushenko, V. M. \& Holets, T. A. (2008). Kohnityvna kontseptsiia kros-kulturnoho menedzhmentu [Cognitive concept of cross-cultural management]. Bulletin of SSU. "Economy” series. No.1. pp. 120 128. [in Ukrainian].

9. Pro priorytetni zakhody shchodo spryiannia zmitsnenniu natsionalnoi yednosti ta konsolidatsii ukrainskoho suspilstva, pidtrymky initsiatyv hromadskosti u tsii sferi (2016). [On priority measures to promote the strengthening of national unity and consolidation of Ukrainian society, support for public initiatives in this area]. Decree of the President of Ukraine of December 1, 2016. Available at: https:// zakon.rada.gov.ua/laws/show/534/2016\#Text[in Ukrainian].

10. Pro skhvalennia Kontseptsii rozvytku hromadianskoi osvity v Ukraini [On approval of the Concept of development of civic education in Ukraine]. Order of the Cabinet of Ministers of Ukraine of October 3, 2018 № 710-r. Available at: https://zakon.rada.gov.ua/ laws / show / 710-2018$\%$ D1\% 80 \# Text. [in Ukrainian].

11. Savchuk, B. \& Mishchuk, D. (2020). Osvitnie seredovyshche universytetu: metodolohichnyi dyskurs u konteksti skladannia mizhnarodnykh reitynhiv [University educational environment: methodological discourse in the context of compiling international rankings]. Youth and the market. No. 2 (181) pp. $60-$ 64. [in Ukrainian].

12. Iaroshynska, O. O. (2014). Osvitnii prostir vyshchoho navchalnoho zakladu yak kontynuum proektuvannia osvitnoho seredovyshcha profesiinoi pidhotovky maibutnikh fakhivtsiv [Educational space of a higher educational institution as a continuum of designing the educational environment of professional training of future specialists]. Pedagogy of creative personality formation in higher and secondary schools, issue. 35. pp. 558-567. [in Ukrainian].

13. Kilmann, R., Saxlon, M. J. \& Serpa, R. (1986). Issues in Understandingand Changing Culture. California Managment Review, Winter, p. 89. [in Englisn].

Стаття надійшла до редакції 26.01.2021

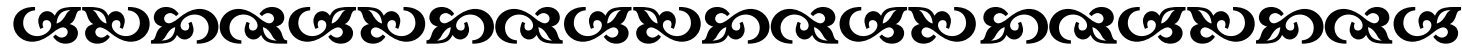

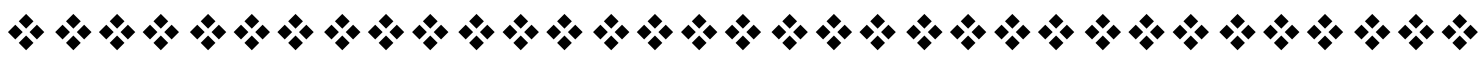

